\title{
COVID-19 : TINGKAT STRES BELAJAR ANAK-ANAK DI DAERAH TERPENCIL
}

\author{
Husin \\ hafizhihusinsungkar@gmail.com \\ Sawitri \\ saresu28101999@gmail.com
}

Sekolah Tinggi Ilmu Alquran (STIQ) Amuntai, Kalimantan Selatan, Indonesia

\begin{abstract}
Abstrak
Pemerintah Indonesia mengeluarkan kebijakan Pembelajaran jarak jauh (PJJ) dalam mencegah penyebaran covid-19 pada satuan pendidikan, yang mana setiap pembelajaran dilakukan tanpa tatap muka langsung seperti belajar di 'rumah aja. Hal ini menimbulkan stres bagi anak didik karena mereka kesulitan memenuhi kebutuhan belajar terutama anak di daerah terpencil. Pada bulan oktober 2020 ada tiga kasus anak meninggal akibat stres belajar dirumah aja karena beberapa alasan yaitu tidak memiliki handphone, kouta internet dan jaringan kurang stabil, kesulitan memahami pembelajaran, banyaknya tugas sekolah, kurangnya pengetahuan orang tua dalam mendampingi anak belajar, sedikitnya waktu orang tua pekerja dalam mendampingi anak belajar, dan terbatasnya kehidupan sosial anak. Tujuan penelitian untuk mengetahui covid-19 dan tingkat stres anak dalam belajar masa pandemi di daerah terpencil. Penelitian ini menggunakan pendekatan kualitatif postpositivistik dengan jenis case study serta prosedur pengumpulan data studi lapangan observasi, angket dan wawancara. Penelitian ini menghasilkan temuan bahwa tingkat stres anak dalam belajar masa pandemi covid-19 di daerah terpencil sangatlah tinggi. Hasil penelitian ini berkontribusi terhadap kajian-kajian dampak PJJ terhadap kualitas psikologi belajar anak sehingga bisa dijadikan sebagai argument untuk menimbang kembali penerapannya dalam proses pembelajaran.
\end{abstract}

Kata Kunci: Covid-19; Tingkat Stres Anak; Daerah Terpencil

\section{PENDAHULUAN}

Coronavirus Disease 2019 (COVID-19) adalah jenis penyakit menular yang disebabkan oleh Severe Acute Respiratory Syndrome Coronavirus 2 (SARS-CoV-2). Virus ini menyerang sistem pernapasan akut seperti flu, infeksi paru-paru, sesak napas, demam, batuk, gagal ginjal dan bahkan kematian. ${ }^{1}$ Virus ini pertama kali ditemukan di kota Wuhan, China. Pada bulan maret 2020 Badan Kesehatan Dunia WHO menyatakan bahwa virus corona menjadi pandemi global karena penularan virus yang sangat cepat

${ }^{1}$ Anung Sugihantono, dan dkk, Pedoman Pencegahan dan Pengendalian Coronavirus Disesase (Covid-19) (Jakarta: Kementerian Kesehatan RI, 2020), h. 17, https://infeksiemerging.kemkes.go.id. 
dan sebagian besar negara di dunia turut terpapar virus ini termasuk Indonesia. ${ }^{2}$ Virus ini menular melalui berbagai cara, yaitu menyebar antara manusia ke manusia lain melewati tetesan cairan dari mulut dan hidung saat orang yang terinfeksi sedang batuk atau bersin, berdekatan dengan penderita positif covid-19 seperti bersentuhan atau berjabat tangan. ${ }^{3}$ Data terkini di negara Indonesia menunjukkan jumlah pasien terkonfirmasi dan positif virus corona dalam 24 jam terakhir terjadi penambahan sebanyak 4.917 kasus setiap hari. Total per hari sampai sekarang sebanyak 516.753 kasus positif, dan total pasien yang dinyatakan sembuh sebanyak 433.649 orang. ${ }^{4}$ Meningkatnya angka kematian akibat virus corona disebabkan oleh dua faktor yaitu faktor dari dalam individu seperti penyakit bawaan yang telah dialami dan kurangnya kesadaran masing-masing individu terhadap virus ini dan faktor eksternal seperti fasilitas rumah sakit yang kurang memadai, peraturan pemerintah yang belum efektif, dan sebagainya. ${ }^{5}$ Infeksi virus corona antar manusia sangatlah cepat. Gejala penyakit dapat bervariasi dari infeksi saluran napas atas hingga ARDS. Diagnosis dilakukan dengan RT-PCR, sehingga saat ini belum ada pengobatan antivirus khusus dan belum ditemukan vaksin untuk COVID-19. ${ }^{6}$ Virus corona belum juga ditemukan penawarnya sampai saat ini. Sudah lebih dari 200 negara di dunia melaporkan adanya kasus virus corona. $^{7}$

Di Indonesia, pandemi Covid-19 berpengaruh besar terhadap berbagai bidang, termasuk bidang pendidikan. Hampir semua lembaga pendidikan terdampak covid-19. Salah satu dampak pandemi covid-19 terhadap sistem pendidikan di semua global yaitu diberhentikannya proses belajar mengajar di sekolah dan penutupan semua sekolah,

${ }^{2}$ Salma Matla Ilpaj dan Nunung Nurwati, “Analisis Pengaruh Tingkat Kematian Akibat Covid-19 Terhadap Kesehatan Mental Masyarakat Di Indonesia," Jurnal Pekerjaan Sosial Vol. 3, no. No. 1 (2020), h. 17.

3 Natasya Virginia Leuwol, "Perubahan Karakter Belajar Mahasiswa Di Tengah Pandemik Covid-19 (Tinjauan Sosio-Psiko terhadap Perubahan Karakter Belajar Mahasiswa di tengah Pandemik COVID-19, di Kota Sorong, Papua Barat)," Civic-Culture: Jurnal Ilmu Pendidikan PKn dan Sosial Budaya Vol. 4, no. N. 1 (2020), h. 33.

${ }^{4}$ Haidar Rais, "Update covid-19 di Indonesia," go.id, prfmnews.id (blog), 2020.

5 Ilpaj dan Nurwati, “Analisis Pengaruh Tingkat Kematian Akibat Covid-19 Terhadap Kesehatan Mental Masyarakat Di Indonesia", h. 18.

${ }^{6}$ Diah Handayani dkk., "Penyakit Virus Corona 2019," Jurnal Respirologi Indonesia Vol. 40, no. No. 2 (2020), h. 128.

${ }^{7}$ Ria Yunitasari dan Umi Hanifah, "Pengaruh Pembelajaran Daring terhadap Minat Belajar Siswa pada Masa COVID-19," Edukatif: Jurnal Ilmu Pendidikan Vol. 2, no. No. 3 (2020), h. 133. 
madrasah, universitas, \& pondok pesantren. ${ }^{8}$ Pada awal april 2020 Kementerian Pendidikan dan Kebudayaan (Kemdikbud) telah menetapkan kebijakan learning from home atau belajar dari rumah (BDR) dengan sistem pembelajaran jarak jauh(PJJ). Undang-undang Nomor 20 Tahun 2003 tentang Sistem Pendidikan Nasional pasal 31 yang menjelaskan Pendidikan jarak jauh berfungsi memberikan layanan pendidikan kepada kelompok masyarakat yang tidak dapat mengikuti pendidikan secara tatap muka atau regular. Dalam konteks yuridis formal, seperti yang termuat dalam PP No.17 Tahun 2010, bab IV tentang penyelenggaraan Pendidikan Jarak Jauh (PJJ), memiliki tujuan untuk perluasan dan pemerataan akses pendidikan, serta meningkatkan mutu dan relevansi pendidikan. ${ }^{9}$

Dalam pelaksanaannya PJJ dibagi menjadi dua pendekatan, yaitu PJJ dalam jaringan (daring) dan PJJ luar jaringan (luring). Guru-guru yang selama ini belum paham teknologi, mau tidak mau harus berlatih agar lebih ahli dalam teknologi. Hal ini berlaku tidak hanya di kota besar saja tetapi juga guru-guru di wilayah 3T (terdalam, terluar, tertinggal) yang belum terjangkau oleh internet. ${ }^{10}$ Dengan diberlakukannya sistem pembelajaran ini, semua proses pembelajaran berubah mulai dari metode pembelajaran, penganggaran, sampai sasarannya. Perubahan ini membutuhkan adaptasi supaya aktivitas belajar-mengajar berjalan efektif. ${ }^{11}$ Guru dan siswa diharuskan untuk belajar secara online dan menjalankan social distancing selama pandemi covid-19. Meski demikian dampak adanya PJJ dengan sistem belajar dari rumah sangatlah terasa, karena keterbiasaan siswa dalam belajar di sekolah dan bertatap muka langsung dengan guru serta belajar bersama teman-teman tidak bisa dilakukan lagi. ${ }^{12}$ Kemudian, anak yang biasanya rata-rata menghabiskan waktu minimal 5 jam di sekolah, kini mereka

8 Khamim Zarkasih Putro dkk., "Pola Interaksi Anak Dan Orangtua Selama Kebijakan Pembelajaran di Rumah," Fitrah: Journal of Islamic Education Vol. 1, no. No. 1 (2020), h. 133.

9 Aniq Amalia dan Siti Fatonah, "Penerapan Pembelajaran Daring Dragonlearn pada Era Pandemic Covid-19(Studi Kasus di MI Ma'had Islam Kopeng)," ISEJ: Indonesian Science Education Journal Vol. 1, no. No. 3 (2020): 152.

${ }^{10}$ Saskia Rosita Indasari dkk., Buku Saku Dukungan Psikososial Bagi Guru \& Siswa Tangguh di Masa Pandemi Covid-19 (Tangerang Selatan: Wahana Visi Indonesia, 2020), h. 8.

${ }^{11}$ Putro dkk., "Pola Interaksi Anak Dan Orangtua Selama Kebijakan Pembelajaran di Rumah", h. 134.

12 A Risalah dkk., "Dampak pandemi covid-19 terhadap kegiatan belajar mengajar di MI/SD (studi KBM berbasis daring bagi guru dan siswa)," JIEES : Journal of Islamic Education at Elementary School Vol. 1, no. No. 1 (2020), h. 11. 
harus tetap di rumah selama 24 jam dengan interaksi fisik yang terbatas dengan teman sebaya atau orang lain diluar rumah. ${ }^{13}$

Beragam reaksi bermunculan ketika kebijakan PJJ diberlakukan, terutama dari pihak orangtua dan peserta didik yang merasa kesulitan mengikuti proses belajar dari rumah. Melalui pembelajarn daring pada bidang pendidikan akan menimbulkan suatu lingkungan belajar modern. Para pakar menyatakan bahwa segala sumber daya mesti dikerahkan sepenuhnya agar tercipta pembelajaran daring efektif. ${ }^{14}$ Di indonesia banyak keluarga yang kurang siap menghadapi kebijakan tersebut. Hal ini disebabkan oleh pihak sekolah yang kurang memaksimalkan pembelajaran selama pandemi, ditambah dengan orangtua yang memiliki kesibukan bekerja atau orangtua yang minim pengetahuan saat mendampingi anak. ${ }^{15}$ Menurut In Setyorini belajar dari rumah secara online selama pandemi covid-19 telah menghabiskan banyak biaya karena harus memenuhi kebutuhan dan kelengkapan fasilitas belajar. ${ }^{16}$

Selama proses belajar dari rumah secara daring atau luring, guru memberikan materi serta tugas pelajaran melalui online. Namun hal tersebut tidaklah selalu berjalan dengan baik, terdapat banyak kendala dalam pelaksanaannya terutama di daerah terpencil yang serba terbatas seperti fasilitas belajar daring. ${ }^{17}$ Keterbatasan tersebutlah yang membuat banyak anak kesulitan dan merasa tidak terbimbing dengan baik dalam memahami pelajaran di sekolah. Selama belajar dari rumah siswa dituntut untuk selalu bisa memahami pelajaran yang diberikan oleh guru dengan keterbatasan yang ada. ${ }^{18}$ Selain itu, rasa bosan yang dialami anak selama belajar dirumah membuat mereka menjadi stres karena pada awalnya sifat anak-anak itu adalah bereksplorasi dengan

${ }^{13}$ Indasari dkk., Buku Saku Dukungan Psikososial Bagi Guru \& Siswa Tangguh di Masa Pandemi Covid-19, h. 8.

${ }^{14}$ Wahyudin Darmalaksana dkk., "Analisis Pembelajaran Online Masa WFH Pandemic Covid-19 sebagai Tantangan Pemimpin Digital Abad 21," Karya Tulis Ilmiah (KTI) Masa Work From Home (WFH) Covid-19, 2020, h. 2.

${ }^{15}$ Priarti Megawanti, Erna Megawati, dan Siti Nurkhafifah, "Persepsi Peserta Didik Terhadap PJJ Pada Masa Pandemi Covid 19,” Faktor Jurnal Ilmiah Kependidikan Vol. 7, no. No. 2 (2020), h. 76.

${ }^{16}$ In Setyorini, "Pandemi covid-19 dan online learning: apakah berpengaruh terhadap proses pembelajaran pada kurukulum 13," Journal of Industrial Engineering \& Management Research (JIEMAR) Vol. 1, no. No. 1 (2020): 98, https://doi.org/10.7777/jiemar.v1i1.

${ }^{17}$ Nika Cahyati dan Rita Kusumah, "Peran Orang Tua Dalam Menerapkan Pembelajaran Di Rumah Saat Pandemi Covid 19," Jurnal Golden Age, Universitas Hamzanwadi Vol. 4, no. No. 1 (2020): h. 155 .

${ }^{18}$ Risalah dkk., "Dampak pandemi covid-19 terhadap kegiatan belajar mengajar di MI/SD (studi KBM berbasis daring bagi guru dan siswa)", h. 11. 
lingkungan. ${ }^{19}$ Bosan atau jenuh diartikan sebagai suatu kondisi psikologis yang ditandai dengan kelelahan ekstrim akibat tuntutan yang terlalu berlebihan. Kelelahan tersebut berupa kelelahan fisik, emosional, dan psikologis yang kemudian termanifestasikan dalam bentuk perilaku yang tidak produktif, bahkan menarik diri dari aktivitas-aktivitas sebelumnya. ${ }^{20}$ Menurut data Lembaga Bantuan Anak Indonesia (LBAI), di saat pandemi COVID-19 banyak anak yang mengalami stres karena tekanan belajar dari rumah. Stres ini berimplikasi secara luas pada masalah-masalah fisik maupun psikologis anak. ${ }^{21}$ Stress yang terjadi terus-menerus tanpa diikuti adanya penanganan yang baik, maka akan menimbulkan individu yang kehilangan minat terhadap aktivitasnya dan mempertanyakan lagi kemampuan diri terhadap nilai aktivitas tersebut. $^{22}$

Berdasarkan latar belakang yang telah dijelaskan di atas, maka peneliti akan menyajikan tentang "Covid-19 dan Tingkat Stres Anak Dalam Belajar Masa Pandemi di Daerah Terpencil" sebagai usaha untuk memberikan kontribusi terhadap kajian-kajian tentang dampak pembelajaran jarak jauh pada kualitas psikologi belajar anak sehingga bisa dijadikan sebagai argumen untuk menimbang kembali penerapannya dalam proses pembelajaran.

\section{METODE PENELITIAN}

Penelitian ini menggunakan pendekatan kualitatif yang berlandaskan pada filsafat post-positivistik dengan jenis penelitian studi kasus (case study). Filsafat postpositivistik memandang penelitian atau penyelidikan sebagai suatu rangkaian yang terdiri atas langkah atau tahap keyakinan pada berbagai perspektif dari para partisipan dan mendukung metode pengumpulan serta analisis data yang cermat. ${ }^{23}$ Pengumpulan

${ }^{19}$ A Tabi'in, "Problematika Stay At Home Pada Anak Usia Dini Di Tengah Pandemi Covid 19," Jurnal Golden Age, Universitas Hamzanwadi Vol. 04, no. No. 1 (2020), h. 193.

${ }^{20}$ Desy Rinawati dan Eka Kurnia Darisman, "Survei tingkat kejenuhan siswa SMK belajar di rumah pada mata pelajaran produk kreatif dan kewirausahaan selama masa pandemi covid-19," Journal of Science and Education (JSE) Vol. 1, no. No. 1 (2020), h. 33.

${ }^{21}$ Amalia Meutia, "Dampak Pandemi Covid 19 Pada Psikis Dan Ingatan Anak," ESJ (Elementary School Journal) Vol. 10, no. No. 1 (2020), h. 62.

${ }^{22}$ Rinawati dan Darisman, "Survei tingkat kejenuhan siswa SMK belajar di rumah pada mata pelajaran produk kreatif dan kewirausahaan selama masa pandemi covid-19”, h. 33. 2016), h. 54.

${ }^{23}$ Punaji Setyosari, Metode penelitian pendidikan dan pengembangan (Jakarta: Prenada Media, 
data pada penelitian ini menggunakan teknik angket survei. Teknik angket survei ini dilakukan untuk melihat fenomena yang terjadi di tempat penelitian. Subjek penelitian adalah siswa SD/MI mulai kelas 4 hingga kelas 6 dan siswa SMP/MTs mulai kelas 7 hingga kelas 9 yang melakukan kegiatan belajar dari rumah selama masa pendemi covid-19 di daerah terpencil. Dalam proses pengambilan sampel di setiap tingkatan kelas peneliti menggunakan teknik proporsional random. Teknik tersebut merupakan cara pengambilan sampel dari anggota populasi menggunakan cara acak tanpa memperhatikan strata pada populasi tersebut. Jumlah keseluruhan sampel yang digunakan dalam penelitian ini adalah sebanyak 50 peserta didik di 10 kecamatan di Kabupaten Hulu Sungai Utara, diantaranya Kecamatan Amuntai Selatan, Kecamatan Amuntai Tengah, Kecamatan Amuntai Utara, Kecamatan Babirik, Kecamatan Banjang, Kecamatan Haur Gading, Kecamatan Danau Panggang, Kecamatan Paminggir, Kecamatan Sungai Pandan dan Kecamatan Sungai Tabukan.

Angket survei yang digunakan pada penelitian ini meliputi instrumen untuk mengukur tingkat stres anak dalam belajar masa pendemi di daerah terpencil. Selain itu juga peneliti menyiapkan lembar observasi dan wawancara untuk peserta didik agar dapat mendiskripsikan covid-19 dan tingkat stres anak dalam belajar masa pendemi di daerah terpencil. Angket ini disebarkan melalui berbagai media, dan melibatkan tenaga survei dan observer dari teman-teman peneliti yang berada di daerah mereka masingmasing yang mempunyai adik atau keluarga yang masih sekolah tingkat SD/MI sampai SMP/Mts untuk di sebar kepada responden. Hasilnya akan di kirim kembali secara virtual untuk di analisis. Teknik analisis data yaitu ada tiga tahapan yakni mereduksi data, penyajian data, dan penarikan kesimpulan. Kegiatan dalam menganalisis data dilakukan secara berkesinambungan sampai tuntas. ${ }^{24}$ Kemudian peneliti melakukan pengecekan keabsahan data untuk mengurangi terjadinya kesalahan data dengan ketekunan pengamat dan triangulasi.

\section{HASIL DAN PEMBAHASAN}

\section{A. Kebijakan Pembelajaran Jarak Jauh Masa Pandemi COVID-19 di Indonesia}

\footnotetext{
${ }^{24}$ Sugiyono, metode penelitian kombinasi (mixed methods) (Bandung: Penerbit Alfabeta, 2016), h. 343.
} 
Kemunculan wabah virus corona yang menyerang hampir semua negara di dunia, telah memberikan tantangan besar bagi lembaga pendidikan. Dalam mengatasi permasalahan ini pemerintah telah mengeluarkan berbagai kebijakan seperti social and physical distancing, isolasi, hingga pembatasan sosial berskala besar (PSBB). Upaya pemerintah untuk tetap menjaga dunia pendidikan bisa berjalan dengan baik yaitu dengan menghimbau lembaga pendidikan dan para pendidik agar mendukung psysical distancing ditengah Pandemi covid-19 sesuai intruksi presiden untuk tetap dirumah, belajar dirumah, bekerja dirumah, ibadah dirumah. ${ }^{25}$. Di indonesia pada masa pandemi covid-19, kebijakan PJJ diberlakukan sebagai bentuk upaya pencegahan penyebaran virus ini. Pada protokol pencegahan penyebaran virus Covid-19 disebutkan bahwa masyarakat diminta untuk menghindari kerumunan atau pengumpulan orang. Hal ini menyebabkan pembelajaran di suatu lembaga pendidikan di tutup sementara, karena sifatnya mengumpulkan banyak orang dan interaksi langsung antara pendidik dan peserta didik dalam satu lingkungan sekolah yang akan menjadi tempat memiliki potensi tinggi untuk terjadinya penyebaran virus covid-19. Oleh karena itu, pembelajaran jarak jauh menjadi upaya penting dalam rangka memutus penyebaran virus secara luas, khususnya dikalangan pengajar dan pembelajar. ${ }^{26}$

Sejak kemendikbud menetapkan aturan "belajar dari rumah", penggunaan teknologi informasi sebagai sarana pendidikan semakin meningkat. Eggy mengatakan bahwa penggunaan aplikasi WA telah meningkat sebesar $40 \%$. Selain menjadi media komunikasi, Whatsapp (WA) kini menjadi media pembelajaran. Tidak hanya WA saja, aplikasi lain yang dinilai dapat menunjang proses pembelajaran juga ikut meningkat. Tersampaikannya informasi dengan cepat adalah bagian dari dampak digital yang bernilai positif, namun kehadiran digital juga membawa dampak negatif sehingga generasi bangsa harus mendapatkan dampingan agar moral dan sikap selalu terjaga. ${ }^{27}$

\footnotetext{
${ }^{25}$ Yunitasari dan Hanifah, "Pengaruh Pembelajaran Daring terhadap Minat Belajar Siswa pada Masa COVID-19", h. 134.

${ }^{26}$ Abdul Latip, "Peran Literasi Teknologi Informasi Dan Komunikasi Pada Pembelajaran Jarak Jauh Di Masa Pandemi Covid-19," EduTeach: Jurnal Edukasi dan Teknologi Pembelajaran Vol. 1, no. No. 2 (2020), h. 109.

${ }^{27}$ Mohammad Makinuddin, Saeful Anam, dan Shoffiyah, "Character Building dan Pendidikan Islam di Era New Normal,” MIYAH: Jurnal Studi Islam Vol. 16, no. No. 1 (2020), h. 189.
} 
Di Indonesia telah digegerkan dengan berita anak bunuh diri akibat belajar dari rumah dengan sistem pembelajaran jarak jauh secara daring. Pada bulan Oktober terdapat 3 kasus anak meninggal dunia, baik dengan cara bunuh diri, atau dibunuh oleh orangtuanya hanya gara-gara kesulitan belajar daring. Kasus pertama, terjadi di Tarakan, Kalimantan Utara yang mana seorang siswa SMP berusia 15 tahun nekat bunuh diri dengan gantung diri dikamarnya karena merasa berat menjalani pembelajaran jarak jauh. ${ }^{28}$ Kasus kedua, terjadi di Gowa, sulawesi selatan yang mana seorang siswi SMA berusia 17 tahun nekat meminum racun rumput hingga meninggal. Hal ini disebabkan sulitnya belajar dari rumah selama PJJ dan keterbatasan kouta internet serta ditambah lagi kisah asmara yang kandas membuat siswi tersebut melakukan bunuh diri. 29 Kasus ketiga, terjadi di Tarakan, kalimantan Utara yang mana seorang siswa Mts berusia 15 tahun nekat bunuh diri karena tidak sanggup menghadapi banyaknya tugas sekolah selama belajar daring dari rumah. ${ }^{30}$

Komisi Perlindungan Anak Indonesia (KPAI) telah menerima 51 laporan dari berbagai daerah yang menyatakan anak menjadi tertekan dan kelelahan karena beban tugas. Waktu pengumpulan yang diberikan sedikit, padahal tugasnya banyak yang harus dikerjakan segera dari guru yang lain. Hal ini bisa menimbulkan masalah kesehatan fisik dan mental bagi anak yang justru akan memengaruhi imunitasnya. Witherington mengatakan, bahwa usia 9-12 tahun telah memiliki ciri perkembangan sikap individualis yang mana tahapan ini anak berusaha untuk mengenal siapa dirinya dengan membandingkan diri dengan teman sebayanya. Jika proses itu tanpa bimbingan, anak akan cenderung kesulitan beradaptasi dengan lingkungannya. ${ }^{31} \mathrm{Hal}$ inilah yang mengharuskan kementrian pendidikan dan budaya untuk mengevaluasi kembali

\footnotetext{
${ }^{28}$ Vega Dhini Lestari, “Terjadi lagi siswa bunuh diri gara-gara sekolah daring, KPAI : Dia tidak kuat menanggung sendirian," tribunnews.net, Tribunnewmaker.com (blog), 2020, https://newsmaker.tribunnews.com/2020/10/30/terjadi-lagi-siswa-bunuh-diri-gara-gara-sekolah-daringkpai-dia-tidak-kuat-menanggungnya-sendirian.

${ }^{29}$ Muhammad Yunus, "Siswi Bunuh Diri Di Gowa, Kpai Sayangkan Pernyataan Fitri Ari Utami," suara.com, suarasulsel.id (blog), 2020, https://sulsel.suara.com/read/2020/10/22/165903/siswi-bunuhdiri-di-gowa-kpai-sayangkan-pernyataan-fitri-ari-utami.

${ }^{30}$ Adhi Wicaksono, "KPAI Sebut siswa bunuh diri diduga banyak tugas selama PJJ," transmedia, CNNIndonesia.com (blog), 2020, https://m.cnnindonesia.com/nasional/20201031194605-20-564467/kpaisebut-siswa-bunuh-diri-diduga-banyak-tugas-selama-pjj.

${ }^{31}$ Tri Nathalia Palupi, "Tingkat Stres Pada Siswa-Siswi Sekolah Dasar Dalam Menjalankan Proses Belajar Di Rumah Selama Pandemi Covid-19,” JP3SDM Vol. 9, no. No. 2 (2020), h. 19.
} 
kebijakan belajar dari rumah dengan sistem pembelajaran jarak jauh secara daring, agar tercipta pembelajaran yang efektif, nyaman dan baik.

\section{B. Belajar Dari Rumah Bagi Anak Daerah Terpencil di Kabupaten Hulu Sungai} Utara

Pada tanggal 23 maret 2020 bapak bupati Hulu Sungai Utara(HSU) yaitu H. Abdul Wahid HK, mengeluarkan surat edaran Nomor: 360/66/BPBD/2020 tentang pencegahan penyebaran/penularan covid-19 di satuan pendidikan kabupaten Hulu Sungai Utaradengan bunyi sebagai berikut: Pertama, satuan pendidikan di wilayah Kabupaten HSU mulai dari (TK/RA/KB/TPA), Sekolah Dasar (SD)/Madrasyah Ibtidaiyah (MI)/Sederajat, dan Sekolah Menengah Pertama (SMP)/Madrasah Tsanawiyah (MTs)/ Sederajat terhitung sejak tanggal 24 Maret 2020 agar melakukan pembelajaran jarak jauh tanpa peserta didik harus datang ke satuan pendidikan. Kedua, bagi semua kepala satuan pendidikan dan para pendidik agar bisa menjadwalkan teknis PJJ baik melalui daring maupun luring dengan memanfaatkan jasa yang disediakan lembaga penyedia sarana pembelajaran dan kementrian pendidikan dan budaya Republik Indonesia secara gratis seperti yang tertera pada lampiran yang merupakan satu bagian tidak terpisahkan dari surat edaran ini. Ketiga, khusus bagi peserta didik kelas VI dan IX agar diberikan perhatian khusus dalam pola pembelajaran jarak jauh ini, baik melalui pemberian tugas belajar di rumah maupun pola try out daring, dalam rangka persiapan menghadapi Ujian Sekolah (US), Ujian Akhir Sekolah dan/atau Ujian Nasional Berbasis Komputer (UNBK). Keempat, Untuk Pendidik/Guru dan Tenaga Kependidikan (PTK) agar mengawasi aktivitas peserta didik di lingkungan masingmasing dengan cara mengefektifkan komunikasi dengan orangtua/wali maupun dengan peserta didik. Kelima, bagi para Pendidik/Guru dan Tenaga Kependidikan (PTK) agar tidak bepergian meninggalkan daerah selama masa PJJ, kecuali ada keperluan yang sangat mendesak dan tidak dapat ditunda setelah mendapatkan izin dari Kepala Dinas Pendidikan Kabupaten Hulu Sungai Utaradan Kepala Kantor Kementerian Agama Kab. HSU. ${ }^{32}$

32 Abdul Wahid HK, "Surat Edaran: Tentang Pencegahan Penyebaran/Penularan Covid-19 (Corona Virus Disease) di Satuan Pendidikan Kabupaten Hulu Sungai Utara," Surat edaran resmi, 2020. 
Kebijakan yang telah diedarkan tersebut menghasilkan perubahan yang menarik dalam bidang pendidikan yaitu situasi kelompok sosial. Kesatuan sosial yang terdiri atas dua atau lebih individu yang telah mengadakan interaksi sosial secara intensif dan teratur, sudah dapat pembagian tugas, struktur, dan norma-norma tertentu. ${ }^{33}$ Pembelajaran daring adalah bentuk pembelajaran jarak jauh yang memanfaatkan teknologi telekomunikasi dan informasi, misalnya internet, CD-ROOM. ${ }^{34}$ Kegiatan pembelajaran yang dilakukan dari rumah selama masa pandemi yaitu melalui perangkat personal computer (PC), laptop dan gadget yang terhubung dengan koneksi jaringan internet. Melalui media ini, pendidik dapat melakukan pembelajaran yang sama di waktu yang sama menggunakan grup di media sosial, diantaranya: telegram, instagram, whatsApp, Google meeting, Google Classroom, Zoom, dan lainnya. ${ }^{35}$

Pembelajaran jarak jauh secara daring mengakibatkan terjadinya gangguan dalam kegiatan pembelajaran oleh guru, siswa, dan orang tua siswa. Pembelajaran daring menyebabkan dampak pada psikis anak dan bisa menurunkan kualitas keterampilan anak didik. Hal tersebut merupakan tanggung jawab setiap bagian pendidikan dalam sarana prasarana untuk kegiatan pembelajaran bagi semua kalangan pendidikan guna melakukan PJJ untuk mengurangi kerugian dunia pendidikan di masa mendatang. Komisi Perlindungan Anak Indonesia menyatakan bahwa anak mengalami kesulitan selama PJJ dalam jaringan data menghasilkan sebesar 77,80\% tugas yang diberikan banyak menumpuk, sebesar $42,20 \%$ anak tidak memiliki kuota yang memadai, sebesar 37,10\% waktu belajar yang diberikan sedikit, sebesar 15,60\% anak tidak memiliki peralatan yang dibutuhkan seperti handphone, Laptop, dan sebaginya. ${ }^{36}$.

\section{Hasil Rekapitulasi Angket Beserta Jawabannya}

\footnotetext{
${ }^{33}$ Subarto, "Momentum Keluarga Mengembangkan Kemampuan Belajar Peserta Didik Di Tengah Wabah Pandemi Covid-19," 'Adalah: Buletin Hukum dan Keadilan Vol. 4, no. No. 1 (2020), h. 14, https://doi.org/10.15408/adalah.v4i1.15383.

${ }^{34}$ Ali Sadikin dan Afreni Hamidah, "Article Pembelajaran Daring di Tengah Wabah Covid-19," BIODIK: Jurnal Ilmiah Pendidikan Biologi Vol. 6, no. No. 2 (2020), h. 216.

35 Arief Rachman Badrudin, Muhammad Hidayat Ginanjar, dan Wartono, "Efektifitas Pembelajaran Jarak Jauh Berbasis Daring Selama Pandemi Covid 19 Pada Jenjang Sekolah Dasar Di Bogor," Edukasi Islami: Jurnal Pendidikan Islam Vol. 9, no. No. 2 (2020), h. 210, https://doi.org/DOI : 10.30868/ei.v9i02.909.

${ }^{36}$ Laila Nur Alfiah, Deni Ainur Rokhim, dan Intan Ayu Idha W, "Analisis Dampak Anjuran Pemerintah Terhadap Belajar Di Rumah Bagi Pelaku Pendidikan," JAMP: Jurnal Adminitrasi dan Manajemen Pendidikan Vol. 3, no. No. 3 (2020), h. 218.
} 
Tabel 1. Angket mengukur tingkat stres anak dalam belajar masa pandemi di daerah terpencil Kabupaten Hulu Sungai Utara

\begin{tabular}{|c|c|c|c|c|c|}
\hline \multirow[t]{2}{*}{ No. } & \multirow[t]{2}{*}{ Pernyataan } & \multicolumn{4}{|c|}{ Jawaban responden } \\
\hline & & SS & $\mathbf{S}$ & KS & TS \\
\hline 1. & $\begin{array}{l}\text { Saya merasa sulit dalam memahami materi } \\
\text { pembelajaran selama proses belajar dari } \\
\text { rumah saat pandemi. }\end{array}$ & 9 & 38 & 2 & 1 \\
\hline 2. & $\begin{array}{l}\text { Saya tidak bisa berkonsentrasi selama } \\
\text { belajar dari rumah saat pandemi. }\end{array}$ & 5 & 38 & 3 & 4 \\
\hline 3. & $\begin{array}{l}\text { Saya merasa bingung untuk mencari sumber } \\
\text { belajar selama proses belajar dari rumah saat } \\
\text { pandemi. }\end{array}$ & 5 & 37 & 5 & 3 \\
\hline 4. & $\begin{array}{l}\text { Saya kesulitan mendapatkan akses internet } \\
\text { selama belajar dari rumah saat pandemi. }\end{array}$ & 5 & 30 & 11 & 4 \\
\hline 5. & $\begin{array}{l}\text { Saya tidak memiliki fasilitas belajar yang } \\
\text { memadai selama proses belajar dari rumah } \\
\text { saat pandemi (smartphone, kouta...) }\end{array}$ & 7 & 25 & 12 & 6 \\
\hline 6. & $\begin{array}{l}\text { Orang tua atau keluarga saya merasa } \\
\text { kesulitan dalam membimbing saya selama } \\
\text { belajar dari rumah saat pandemi. }\end{array}$ & 8 & 34 & 6 & 2 \\
\hline 7. & $\begin{array}{l}\text { Saya merasa putus asa saat mengerjakan } \\
\text { tugas yang kurang dimengerti selama belajar } \\
\text { dari rumah saat pandemi. }\end{array}$ & 4 & 34 & 8 & 4 \\
\hline 8. & $\begin{array}{l}\text { Saya sering merasa sakit kepala saat } \\
\text { mengerjakan tugas yang banyak selama } \\
\text { belajar dari rumah saat pandemi. }\end{array}$ & 5 & 29 & 12 & 4 \\
\hline 9. & $\begin{array}{l}\text { Saya merasa belajar dari rumah itu } \\
\text { membosankan. }\end{array}$ & 14 & 29 & 5 & 2 \\
\hline 10. & $\begin{array}{l}\text { Saya merasa tuntutan dari orang tua untuk } \\
\text { terus mengerjakan tugas yang diberikan oleh } \\
\text { guru tanpa pemahaman materi yang jelas } \\
\text { membuat saya stres. }\end{array}$ & 10 & 33 & 4 & 3 \\
\hline 11. & $\begin{array}{l}\text { Saya merasa frustasi saat orang tua atau } \\
\text { keluarga saya tidak bisa mendampingi } \\
\text { selama belajar dari rumah saat pandemi dan } \\
\text { mengerjakan tugas yang diberikan. }\end{array}$ & 3 & 36 & 5 & 6 \\
\hline 12. & $\begin{array}{l}\text { Saya merasa berat badan saya menurun } \\
\text { karena pola makan yang tidak teratur selama } \\
\text { belajar dari rumah saat pandemi. }\end{array}$ & 2 & 22 & 16 & 10 \\
\hline 13. & $\begin{array}{l}\text { Saya cepat merasa lelah selama belajar dari } \\
\text { rumah saat pandemi. }\end{array}$ & 6 & 34 & 7 & 3 \\
\hline 14. & $\begin{array}{l}\text { Saya sering merasa cemas dan gelisah } \\
\text { selama belajar dari rumah. }\end{array}$ & 4 & 26 & 17 & 3 \\
\hline 15. & $\begin{array}{l}\text { Saya sering bangun kesiangan selama } \\
\text { belajar dari rumah saat pandemi. }\end{array}$ & 9 & 24 & 13 & 4 \\
\hline 16. & Belajar dari rumah membuat saya jarang & 4 & 27 & 9 & 10 \\
\hline
\end{tabular}




\begin{tabular}{|l|l|c|c|c|c|}
\hline & bermain dengan teman-teman. & & & \\
\hline 17. & $\begin{array}{l}\text { Belajar dari rumah secara online saat } \\
\text { pandemi membuat saya sering bermain } \\
\text { handphone. }\end{array}$ & 15 & 31 & 2 & 2 \\
\hline 18. & $\begin{array}{l}\text { selama mengikuti pembelajaran dari rumah } \\
\text { saat pandemi membuat emosional saya } \\
\text { meningkat. }\end{array}$ & 4 & 32 & 12 & 2 \\
\hline 19. & $\begin{array}{l}\text { Belajar dari rumah secara online saat } \\
\text { pandemi membuat saya menutup diri dari } \\
\text { dunia luar dan lebih sering berada dirumah. }\end{array}$ & 4 & 26 & 15 & 5 \\
\hline 20. & $\begin{array}{l}\text { Belajar dari rumah saat pandemi membuat } \\
\text { saya malas untuk beraktifitas lain. }\end{array}$ & 9 & 27 & 9 & 5 \\
\hline \multicolumn{1}{|l|}{ Jumlah } & 132 & 612 & 173 & 83 \\
\hline
\end{tabular}

(Sumber : Dokumentasi, 23 November 2020) 
Diagram 1. Persentase tinggi tingkat stres anak dalam belajar masa pandemi di daerah terpencil Kabupaten Hulu Sungai Utara

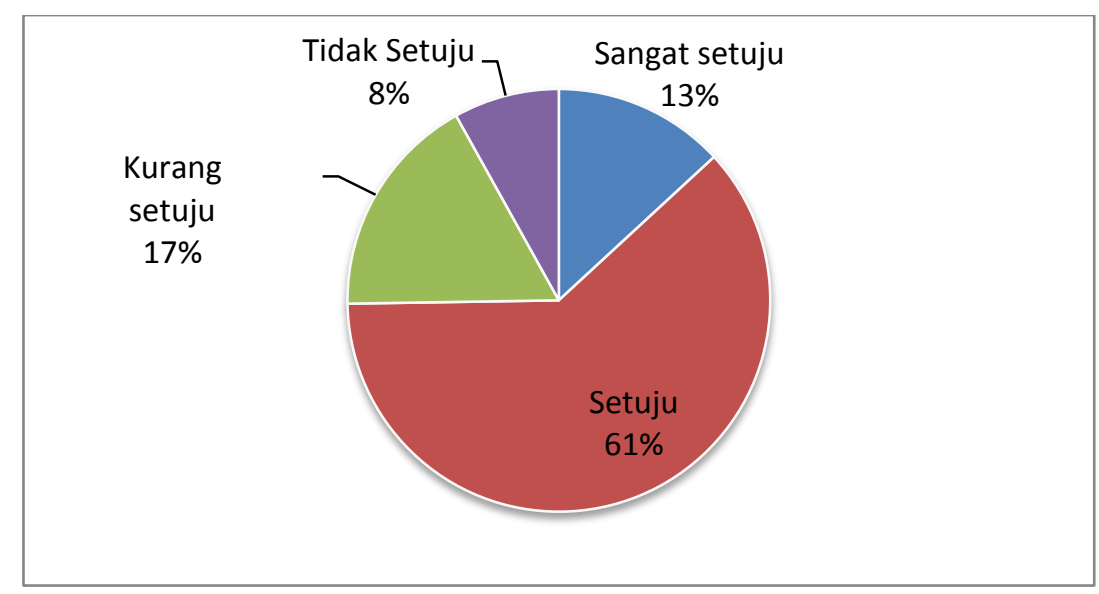

(Sumber : Dokumentasi, 23 November 2020)

Berdasarkan data tabel dari angket mengenai tingkat stres anak dalam belajar masa pandemi di daerah terpencil kabupaten Hulu Sungai Utaradiatas dapat diketahui jawaban dari 50 responden menyatakan sangat setuju rata-rata sebesar 13\%, responden menjawab setuju rata-rata sebesar $61 \%$, responden menjawab kurang setuju rata-rata sebesar $17 \%$, dan responden menjawab tidak setuju rata-rata sebesar $8 \%$. Dengan demikian dapat disimpulkan bahwa tingkat stres anak dalam belajar masa pandemi di daerah terpecil kabupaten Hulu Sungai Utarasangat tinggi, karena jawaban responden dominan menjawab sangat setuju dan setuju.

Stres diartikan sebagai satu keadaan individu yang terganggu keseimbangannya. Stres terjadi karena adanya situasi luar atau dalam individu yang memunculkan gangguan dan menuntut individu untuk terus memberikan respon adaptif. Selye mengatakan bahwa, stres merupakan suatu respon yang tidak spesifik dari berbagai anggota tubuh. Sedangkan menurut Lazarus dan Folkman, stres terjadi karena akibat dari ketidaksesuaian antara harapan dan fakta (kenyataan). Artinya, stres merupakan reaksi psikologis terhadap anggota tubuh yang membebani kehidupan dan mengganggu kesejahteraan hidup seseorang. Stres belajar merupakan tekanan yang dihadapi anak 
berkaitan dengan sekolah, dipersepsikan secara negatif, dan berdampak pada kesehatan fisik, psikis, dan performansi belajar. ${ }^{37}$

Adapun penyebab tingginya tingkat stres anak dalam belajar masa pandemi di daerah terpencil kabupaten hulu sungai utara, berdasarkan hasil wawancara penulis yang membaginya kedalam 3 aspek yaitu sebagai berikut:

\section{Kebutuhan Fasilitas Belajar Masa Pandemi Untuk Anak Kurang Memadai}

\section{Jaringan internet tidak stabil dan boros pemakaian kouta}

Negara Indonesia dipenuhi dengan kepualauan yang letaknya beragam menyebabkan tidak semua wilayah terjangkau oleh layanan internet. Penyebaran jaringan internet masih belum merata di pelosok negeri, seperti di kabupaten Hulu Sungai Utarayang termasuk daerah terpencil. Tidak semua sekolah baik SD maupun SMP dapat menikmati internet. ${ }^{38}$ Jika pun sudah terjangkau layanan internet namun penyebarannya terkadang tidak stabil sehingga menghambat proses pembelajaran daring dari rumah menyebabkan lambatnya dalam mengakses informasi. Siswa kadang-kadang tertinggal informasi akibat dari sinyal atau jaringan yang kurang memadai. Hal ini mengakibatkan mereka menjadi terlambat dalam mengumpulkan tugas yang diberikan guru. Sedangkan bagi guru yang menilai tugas banyak yang telah diberikan kepada siswa, membuat memori atau ruang penyimpanan HP menjadi penuh. Pelaksanaa pembelajaran online ini juga membuat guru berpikir ulang, mengenai model dan metode pembelajaran yang akan digunakan. Pada awalnya setiap guru sudah mempersiapkan model pembelajaran yang akan digunakan, kemudian harus mengubah model pembelajaran tersebut. ${ }^{39}$

Masalah lain yang anak hadapi adalah bertambahnya biaya pengeluaran seperti biaya membeli paket kuota internet, teknologi online yang memerlukan koneksi jaringan ke internet dan paket data (kouta). Oleh sebab itu, tingkat penggunaaan kuota

${ }^{37}$ Farida Aryani, Stres belajar Suatu pendekatan dan Intervensi konseling (Makassar: EDUKASI MITRA GRAFIKA, 2016), h. 25-26.

38 Anita Wardani dan Yulia Ayriza, "Analisis Kendala Orang Tua dalam Mendampingi Anak Belajar di Rumah Pada Masa Pandemi Covid-19," Jurnal Obsesi : Jurnal Pendidikan Anak Usia Dini Vol. 5, no. No. 1 (2020), h. 779, https://doi.org/10.31004/obsesi.v5i1.705.

${ }^{39}$ Anang Susilo Raharjo, dan dkk, Kutunggu Hadirmu di Depan Layar (Sumatera Utara: format publishing, 2020), h. 10, https://formatpublishing.id. 
internet bertambah dan akan menambah beban pengeluaran siswa. Kesulitan untuk mengisi kuota disebabkan situasi ekonomi yang saat ini juga terdampak. ${ }^{40}$ Kemampuan orang tua untuk memberikan fasilitas pendidikan online seperti penggunaan jaringan internet yang membutuhkan biaya yang tidak sedikit. Kondisi tersebut tampaknya berbeda dengan di Cina yang siap menyediakan infrastruktur pendukung pembelajaran daring di sekolah dengan baik. Sejak beberapa tahun terakhir Pemerintah Cina telah mendirikan sejumlah proyek nasional untuk menyiapkan infrastruktur kegiatan pembelajaran daring di sekolah bahkan membuat proyek sekolah online. ${ }^{41}$

\section{Tidak Memiliki Handphone}

Sekilas mungkin orang akan mengira belajar dari rumah secara daring itu mudah, cukup dengan punya fasilitasnya seperti HP dan kuota serta jaringan yang mendukung, maka kegiatan belajar ini bisa berjalan dengan baik. Hal ini tidaklah seperti yang dipikirkan, setelah beberapa minggu melakukan belajar dari rumah menggunakan sistem online, semua masalah dan kendala mulai bermunculan. Salah satunya tidak semua anak didik sama dalam hal kepemilikan fasilitas seperti HP, banyak di antara para siswa yang hanya memiliki HP, biasa. ${ }^{42}$ Selain itu jika pun ada handphone, itupun milik orangtua mereka. Jika belajar daring mereka harus bergantian menggunakan HP dengan orangtua, dan mendapat giliran setelah orangtua pulang kerja. Hal ini juga sulit karena ada orang tua yang pulang kerja di siang hari, sore hari, bahkan malam hari. Sementara itu, pada umumnya jadwal pembelajaran daring di sekolah dilakukan mulai pagi hingga siang hari. ${ }^{43}$

Alhasil anak didik mengalami kendala, seperti terlambat mengerjakan tugas yang diberikan guru. Akibat terlambat ada siswa yang jenuh akhirnya tidak mengerjakan tugas lagi. Dengan keadaan orangtua siswa tersebut, siswa lebih banyak jauh ketinggalan informasi tentang perkembangan pelajaran dikarenakan tidak memiliki

${ }^{40}$ Leuwol, "Perubahan Karakter Belajar Mahasiswa Di Tengah Pandemik Covid-19 (Tinjauan Sosio-Psiko terhadap Perubahan Karakter Belajar Mahasiswa di tengah Pandemik COVID-19, di Kota Sorong, Papua Barat),", h. 39.

${ }_{41}$ Wardani dan Ayriza, "Analisis Kendala Orang Tua dalam Mendampingi Anak Belajar di Rumah Pada Masa Pandemi Covid-19,", h. 779.

${ }^{42}$ KH. Lalu Gede Muhammad Zainuddin Atsani, "Transformasi Media Pembelajaran Pada Masa Pandemi Covid-19," Al-Hikmah: Jurnal Studi Islam Vol. 1, no. No 1 (2020), h. 87.

43 Asmuni, "Problematika Pembelajaran Daring di Masa Pandemi Covid-19 dan Solusi Pemecahannya," Jurnal Paedagogy: Jurnal Penelitian dan Pengembangan Pendidikan Vol. 7, no. No. 4 (2020), h. 284. 
handphone. Untuk mengurangi permasalahan ini, siswa yang tidak memiliki handphone diharapkan meminjam dari teman, tetangga atau saudara dan selalu bertanya pada teman terkait tugas yang diberikan guru. ${ }^{44}$

\section{Sarana Prasarana Kurang Memadai}

Dalam mengahadapi pembelajaran dari rumah dengan sistem PJJ terdapat dua persiapan yang harus dilakukan sebelum memulai yaitu persiapan diri dan persiapan sarana prasarana. Sarana atau fasilitas belajar merupakan salah satu faktor penentu keberhasilan belajar siswa. Fungsi sarana prasarana ialah untuk membantu segala kegiatan belajar agar hal tersebut dapat berjalan dengan baik. Kebutuhan fasilitas belajar siswa saat di rumah sangat banyak yaitu ruang belajar, buku pelajaran, buku tulis, lampu belajar, pena, pengsil, penggaris, penghapus, dan sebagainya. Ahmadi dan Supriyono mengatakan bahwa "Tempat untuk belajar itu merupakan salah satu sarana terlaksananya belajar secara efisien dan efektif". ${ }^{45}$

Di kabupaten Hulu Sungai Utaraterdapat beberapa lembaga pendidikan yang buku pelajaran untuk anak belajar dari rumah dipakai secara bergantian, karena tidak cukupnya ketersediaan sumber belajar buku. Dari hasil wawancara kepada salah satu anak di kecamatan banjang kabupaten HSU menyatakan bahwa belajar dirumah membuatnya sulit untuk berkonsentrasi. Hal ini dikarenakan tempat belajar yang kurang nyaman dan letak rumah anak di pedalaman yang penuh dengan suara bising binatang serta suhu udara rumah yang panas.

\section{E. Psikologi Anak Selama Belajar Masa Pandemi}

\section{Kesulitan Memahami Pelajaran Dan Tugas Sekolah Yang Banyak}

Salah satu penyebab lain anak menjadi stres yaitu sulitnya memahami materi pembelajaran yang diberikan guru secara daring. kebanyakan guru hanya memberikan materi pelajaran baru tanpa disertai dengan pemahaman yang jelas sehingga anak menjadi kurang paham terhadap pelajaran. Selain itu banyaknya tugas yang diberikan guru selama belajar dari rumah membuat anak terbebani. Anak dituntut untuk belajar

${ }^{44}$ Raharjo, dan dkk, Kutunggu Hadirmu di Depan Layar, h. 176.

45 Darwin Bangun, "Hubungan Persepsi Siswa Tentang Perhatian Orang Tua, Kelengkapan Fasilitas Belajar, Dan Penggunaan Waktu Belajar Di Rumah Dengan Prestasi Belajar Ekonomi," Jurnal Ekonomi \& Pendidikan Vol. 5, no. No. 1 (2020), h. 82. 
mandiri dan memahami setiap pelajaran. Menurut Sharon bahwa "kemandirian belajar adalah proses yang membantu siswa dalam mengatur pikiran, tingkah laku, dan perasaan mereka agar membuat mereka berhasil dalam melayari pengalaman belajar mereka". 46

Sisi negatif lain dalam pembelajaran daring yaitu materi yang didapat tidak sebanding seperti pembelajaran secara tatap muka di sekolah. Hal ini disebabkan karena banyak materi yang belum diselesaikan oleh pendidik. Semua ini menjadi kendala bagi siswa karena tidak sepenuhnya dipahami, ditambah banyak tugas yang diberikan oleh pendidik. ${ }^{47}$ Ada beberapa kerugian yang dirasakan oleh peserta didik ketika terjadi penutupan sekolah sementara. Banyak kegiatan pembelajaran seperti ujian yang mestinya dilakukan oleh peserta didik pada kondisi normal, sekarang dengan adanya covid-19 ujian ditiadakan ataupun diganti dengan penilaian yang lain.

\section{Merasa Bosan/Jenuh Dan Malas Melakukan Aktivitas Lain}

Menurut KBBI, kata bosan berarti sudah tidak suka terhadap sesuatu karena terlalu sering; jemu. ${ }^{48}$ Selama belajar dari rumah masa pandemi, anak akan merasa bosan karena beberapa hal yakni keharusan untuk selalu diam di rumah dan melakukan segala sesuatu di dalam rumah. ${ }^{49}$ Dampak yang dirasakan oleh siswa selama pembelajaran di rumah memaksa siswa untuk belajar jarak jauh membuat anak menjadi bosan dan malas untuk beraktifitas lain, karena siswa terbiasa belajar di sekolah dengan bertemu teman-temannya serta bermain bersama. Sedangkan untuk saat ini, siswa diharuskan untuk belajar di rumah dengan berjaga jarak dalam waktu yang belum bisa dipastikan. Perubahan yang terjadi tersebut membuat anak merasa bingung sehingga daya tanggap belajar anak juga berpengaruh dan anak yang biasanya belajar secara tatap muka harus terpaksa dihentikan sementara dan diganti dengan kegiatan belajar di rumah

${ }^{46}$ Rida Fironika Kusumadewi, Yustiana, dan Khoirotun Nasihah, "Menumbuhkan Kemandirian Siswa Selama Pembelajaran Daring Sebagai Dampak COVID-19 Di SD," JPRD ( Jurna Riset Pendidikan Dasar) Vol. 1, no. No. 1 (2020), h. 11.

${ }^{47}$ Jamilah, "Dampak Pembelajaran Daring di Tengah Pandemi COVID 19 pada Siswa Sekolah Dasar," Prosiding Diskusi Daring Tematik Nasional 2020, 2020, h. 16.

${ }^{48}$ Tim Penyusun Kamus Pusat Bahasa., Kamus Bahasa Indonesia (Jakarta: Pusat Bahasa, 2008), h. 219.

${ }^{49}$ Farida Rohayani, “Menjawab Problematika Yang Dihadapi Anak Usia Dini di Masa Pandemi COVID-19," QAWWAM: JOURNAL FOR GENDER MAINSTREAMING Vol. 14, no. No. 1 (2020), h. 32, https://doi.org/10.20414/Qawwam.v14i1.2310. 
secara online. ${ }^{50}$ Berdasarkan temuan penelitian yang dilakukan oleh Purwanto, pembelajaran jarak jauh atau daring membuat anak-anak jenuh/bosan dan ingin segera ke sekolah bermain dengan temannya. Melihat kondisi ini, siswa perlu pendampingan dan motivasi baik dari guru maupun orang tua. ${ }^{51}$

\section{Emosi Tidak Stabil}

Pandemi Covid dianggap sebagai peristiwa besar yang terjadi atau yang dialami dalam kehidupan seseorang. Kondisi ini tidak hanya menimbulkan perasaan yang tidak nyaman, tetapi juga akan memberikan perubahan pada kehidupan individu sebagai akibat yang dialaminya. Perubahan-perubahan tersebut dapat menimbulkan stres dan emosional yang tidak stabil. Stres yang dialami anak dapat menimbulkan tekanan untuk individu agar ia beradaptasi atau menyesuaikan diri. Stres berimplikasi menyeluruh sacara luas pada masalah-masalah fisik maupun psikis. Menurut data Lembaga Bantuan Anak Indonesia, pandemi COVID-19 telah banyak membuat anak mengalami stres karena tekanan atau tuntutan yang ada saat anak berada di rumah. Hal itu disebabkan karena tubuh anak-anak sedang berkembang, mereka lebih peka terhadap stres berulang dan menanggung beban berat dari sistem ini. Beberapa gejala yang menunjukkan anak yang mengalami stres dapat dilihat dari adanya perubahan perilaku yang ditunjukkan, beberapa di antaranya: bersikap lebih menuntut, merasa cemas, terlihat mulai menarik diri, sulit konsentrasi, mengalami perubahan suasana hati, menunjukkan perilaku gelisah, penurunan atau peningkatan nafsu makan, mengeluh rasa sakit pada perut atau kepala, gejala sudah memengaruhi metabolisme tubuh. ${ }^{52}$

\section{Stres Karena Orang Tua Tidak Bisa Maksimal Mendampingi}

Kurangnya pemahaman materi oleh orang tua merupakan salah satu alasan mengapa orangtua tidak bisa maksimal mendampingi anak belajar dari rumah selama pandemi. Hal ini menjadi kendala dalam pelaksanaannya, disebabkan orang tua tidak bisa memberikan penjelasan tambahan terhadap materi yang telah diberikan guru melalui

\footnotetext{
${ }^{50}$ Aden Fani Rahmasari, Fajar Setiawan, dan Meirza Nanda Faradita, "Pengaruh Pembelajaran Online Terhadap Kemandirian Belajar Siswa Kelas II SD Muhammadiyah 17 Surabaya di Tengah Pandemi Covid-19," Inventa: Jurnal Pendidikan Sekolah Dasar Vol. 4, no. No. 5 (2020), h. 165.

${ }^{51}$ Neneng Yulda Sari dan Wisroni, "The Urgency Of Parental Guidance For Youth Education In The Belajar Dari Rumah (BDR) Era," Jurnal Pendidikan Luar Sekolah (PLS) Vol. 8, no. No. 3 (2020), h. 313, https://doi.org/10.24036/spektrumpls.v8i3.109565.

${ }^{52}$ Meutia, “Dampak Pandemi Covid 19 Pada Psikis Dan Ingatan Anak,”, h. 62.
} 
online. Pemahaman materi luas yang dimiliki oleh orang tua sangat bermanfaat dalam membantu anak belajar dirumah. Irhamna mengatakan dalam penelitiannya "orang tua sangat berperan penting dalam memahami materi yang di berikan dari pihak sekolah untuk meningkatkan kualitas belajar anak didik". Kemudian alasan lain mengapa orang tua tidak bisa maksimal mendampingi anak belajar yaitu tidak memiliki cukup waktu mendampingi anak disebabkan harus bekerja, karena hampir seluruh penduduk di kabupaten HSU adalah seorang petani dan pekebun. Alasan ini lah yang menyebakan anak harus belajar mandiri dan merasa tertekan jika ada materi atau tugas yang tidak bisa dipahami tanpa dampingan orangtua maupun keluarga. Sikap tertekan ini jika berkelanjutan tanpa penanganan yang baik akan menimbulkan dampak besar kepada anak seperti anak merasa stres atau depresi. ${ }^{53}$

\section{F. Kehidupan Sosial Anak Selama Belajar Masa Pandemi}

Penerapan social distancing merupakan upaya pencegahan penyebaran covid 19. Makna dasar social distancing adalah menerapkan jaga jarak antar individu minimal satu meter, tidak berkerumun, tidak membuat acara yang mengumpulkan banyak massa. 54 Oleh karena itu, pembelajaran harus dilakukan di rumah masing-masing atau belajar dari rumah. Pembelajaran daring adalah salah satu hal yang harus dilakukan supaya kegiatan belajar tetap berjalan. Penggunaan media daring dalam proses pembelajaran jarak jauh bisa membantu guru berkomunikasi dengan murid dan memberikan materi pelajaran. ${ }^{55}$ Namun dampak dari semua ini sangat besar terhadap anak terutama di daerah terpencil di kabupaten HSU. Selama kebijakan ini berlangsung telah banyak perubahan yang terjadi pada diri anak. Hal ini sebagaimana hasil dari wawancara peneliti yang mana sebagian anak mengatakan bahwa dengan diberlakukannya PJJ, Social distancing, PSBB membuat mereka jarang keluar rumah, waktu bermain dengan teman sebaya berkurang, mereka cenderung menutup diri dari dunia luar karena sudah

${ }^{53}$ Wardani dan Ayriza, "Analisis Kendala Orang Tua dalam Mendampingi Anak Belajar di Rumah Pada Masa Pandemi Covid-19,", h. 776.

54 Safira Rona Mahmudah, "Pengaruh Pembelajaran Daring terhadap Psikologis Siswa Terdampak Social Distancing Akibat Covid 19," Jurnal Al-Mau'izhoh Vol.2, no. No. 2 (2020), h. 10.

${ }_{55}$ Oktafia Ika Handarini, "Pembelajaran Daring Sebagai Upaya Study From Home (SFH) Selama Pandemi Covid 19," Jurnal Pendidikan Administrasi Perkantoran (JPAP) Vol. 8, no. No. 3 (2020), h. 499. 
mulai terbiasa diam dirumah saja dan berkurangnya waktu berekplorasi mereka tentang pengenalan jati diri serta lingkungan sekitar. ${ }^{56}$

\section{KESIMPULAN}

. Covid-19 merupakan jenis penyakit menular yang disebabkan oleh SARS-CoV2. Virus ini menyerang sistem pernapasan akut seperti flu, infeksi paru-paru, sesak napas, demam, batuk, gagal ginjal dan bahkan kematian. Pada bulan maret 2020 Badan Kesehatan Dunia WHO menyatakan bahwa virus corona menjadi pandemi global karena penularan virus yang sangat cepat dan sebagian besar negara di dunia turut terpapar virus ini termasuk Indonesia. Kemdikbud telah menetapkan kebijakan belajar dari rumah (BDR) dengan sistem pembelajaran jarak jauh (PJJ) sebagai upaya memutus rantai penyebaran virus corona.

Pembelajaran jarak jauh secara daring mengakibatkan terjadinya gangguan dalam kegiatan pembelajaran oleh guru, siswa, dan orang tua siswa. Pembelajaran daring menyebabkan dampak pada psikis anak dan bisa menurunkan kualitas keterampilan anak didik. Komisi Perlindungan Anak Indonesia menyatakan bahwa anak mengalami kesulitan selama PJJ dalam jaringan, data menghasilkan sebesar 77,80\% tugas yang diberikan banyak menumpuk, sebesar 42,20\% anak tidak memiliki kuota yang memadai, sebesar 37,10\% waktu belajar yang diberikan sedikit, sebesar 15,60\% anak tidak memiliki peralatan yang dibutuhkan seperti handphone, Laptop, dan sebagainya. PJJ yang ditetapkan pemerintah untuk belajar dari rumah menimbulkan tingkat stres anak di daerah terpencil tinggi salah satunya seperti di Kabupaten Hulu Sungai Utara.

Berdasarkan hasil dari angket mengenai tingkat stres anak dalam belajar masa pandemi di daerah terpencil Kabupaten Hulu Sungai Utaradiperoleh jawaban dari 50 responden menyatakan sangat setuju rata-rata sebesar $13 \%$, responden menjawab setuju rata-rata sebesar $61 \%$, responden menjawab kurang setuju rata-rata sebesar $17 \%$, dan responden menjawab tidak setuju rata-rata sebesar $8 \%$. Dengan demikian dapat disimpulkan bahwa tingkat stres anak dalam belajar masa pandemi di daerah terpencil kabupaten Hulu Sungai Utara sangat tinggi, karena jawaban responden dominan

56 Wardani dan Ayriza, "Analisis Kendala Orang Tua dalam Mendampingi Anak Belajar di Rumah Pada Masa Pandemi Covid-19,”, h. 776. 
menjawab sangat setuju dan setuju. Hal ini disebabkan kebanyakan anak kesulitan memahami materi pembelajaran karena kurangnya penjelasan guru, minimnya pengetahuan orang tua dalam mendampingi anak, terbatasnya kehidupan sosial anak dan anak cenderung merasa bosan/ jenuh belajar dari rumah serta faslitas belajar yang kurang memadai membuat anak menjadi frustasi dan stres

\section{DAFTAR PUSTAKA}

Alfiah, Laila Nur, Deni Ainur Rokhim, dan Intan Ayu Idha W. "Analisis Dampak Anjuran Pemerintah Terhadap Belajar Di Rumah Bagi Pelaku Pendidikan." JAMP: Jurnal Adminitrasi dan Manajemen Pendidikan Vol. 3, no. No. 3 (2020): 216-23.

Amalia, Aniq, dan Siti Fatonah. "Penerapan Pembelajaran Daring Dragonlearn pada Era Pandemic Covid-19(Studi Kasus di MI Ma'had Islam Kopeng)." ISEJ: Indonesian Science Education Journal Vol. 1, no. No. 3 (2020): 148-64.

Aryani, Farida. Stres belajar Suatu pendekatan dan Intervensi konseling. Makassar: EDUKASI MITRA GRAFIKA, 2016.

Asmuni. "Problematika Pembelajaran Daring di Masa Pandemi Covid-19 dan Solusi Pemecahannya." Jurnal Paedagogy: Jurnal Penelitian dan Pengembangan Pendidikan Vol. 7, no. No. 4 (2020): 281-88.

Atsani, KH. Lalu Gede Muhammad Zainuddin. "Transformasi Media Pembelajaran Pada Masa Pandemi Covid-19.” Al-Hikmah: Jurnal Studi Islam Vol. 1, no. No 1 (2020): 82-93.

Badrudin, Arief Rachman, Muhammad Hidayat Ginanjar, dan Wartono. "Efektifitas Pembelajaran Jarak Jauh Berbasis Daring Selama Pandemi Covid 19 Pada Jenjang Sekolah Dasar Di Bogor." Edukasi Islami: Jurnal Pendidikan Islam Vol. 9, no. No. 2 (2020): 209-44. https://doi.org/DOI : 10.30868/ei.v9i02.909.

Bangun, Darwin. "Hubungan Persepsi Siswa Tentang Perhatian Orang Tua, Kelengkapan Fasilitas Belajar, Dan Penggunaan Waktu Belajar Di Rumah Dengan Prestasi Belajar Ekonomi." Jurnal Ekonomi \& Pendidikan Vol. 5, no. No. 1 (2020): 74-94.

Cahyati, Nika, dan Rita Kusumah. "Peran Orang Tua Dalam Menerapkan Pembelajaran Di Rumah Saat Pandemi Covid 19." Jurnal Golden Age, Universitas Hamzanwadi Vol. 4, no. No. 1 (2020): 152-59.

Darmalaksana, Wahyudin, R. Yuli Ahmad Hambali, Ali Masrur, dan Muhlas. "Analisis Pembelajaran Online Masa WFH Pandemic Covid-19 sebagai Tantangan Pemimpin Digital Abad 21." Karya Tulis Ilmiah (KTI) Masa Work From Home (WFH) Covid-19, 2020, 1-12.

Handarini, Oktafia Ika. "Pembelajaran Daring Sebagai Upaya Study From Home (SFH) Selama Pandemi Covid 19." Jurnal Pendidikan Administrasi Perkantoran (JPAP) Vol. 8, no. No. 3 (2020): 496-503. 
Handayani, Diah, Dwi Rendra Hadi, Fathiyah Isbaniah, Erlina Burhan, dan Heidy Agustin. "Penyakit Virus Corona 2019." Jurnal Respirologi Indonesia Vol. 40, no. No. 2 (2020): 119-29.

HK, Abdul Wahid. Surat edaran resmi. "Surat Edaran: Tentang Pencegahan Penyebaran/Penularan Covid-19 (Corona Virus Disease) di Satuan Pendidikan Kabupaten Hulu Sungai Utara." Surat edaran resmi, 2020.

Ilpaj, Salma Matla, dan Nunung Nurwati. "Analisis Pengaruh Tingkat Kematian Akibat Covid-19 Terhadap Kesehatan Mental Masyarakat Di Indonesia." Jurnal Pekerjaan Sosial Vol. 3, no. No. 1 (2020): 16-28.

Indasari, Saskia Rosita, Adhimas Wahyu Agung Wijaya, Melliana Layuk, Marthen S Sambo, dan Mega Indrawati. Buku Saku Dukungan Psikososial Bagi Guru \& Siswa Tangguh di Masa Pandemi Covid-19. Tangerang Selatan: Wahana Visi Indonesia, 2020.

Jamilah. "Dampak Pembelajaran Daring di Tengah Pandemi COVID 19 pada Siswa Sekolah Dasar." Prosiding Diskusi Daring Tematik Nasional 2020, 2020.

Kusumadewi, Rida Fironika, Yustiana, dan Khoirotun Nasihah. "Menumbuhkan Kemandirian Siswa Selama Pembelajaran Daring Sebagai Dampak COVID-19 Di SD.” JPRD ( Jurna Riset Pendidikan Dasar) Vol. 1, no. No. 1 (2020): 7-13.

Latip, Abdul. "Peran Literasi Teknologi Informasi Dan Komunikasi Pada Pembelajaran Jarak Jauh Di Masa Pandemi Covid-19.” EduTeach: Jurnal Edukasi dan Teknologi Pembelajaran Vol. 1, no. No. 2 (2020): 107-15.

Lestari, Vega Dhini. "Terjadi lagi siswa bunuh diri gara-gara sekolah daring, KPAI : Dia tidak kuat menanggung sendirian." Tribunnews.net. Tribunnewmaker.com (blog), 2020. https://newsmaker.tribunnews.com/2020/10/30/terjadi-lagi-siswabunuh-diri-gara-gara-sekolah-daring-kpai-dia-tidak-kuat-menanggungnyasendirian.

Leuwol, Natasya Virginia. "Perubahan Karakter Belajar Mahasiswa Di Tengah Pandemik Covid-19 (Tinjauan Sosio-Psiko terhadap Perubahan Karakter Belajar Mahasiswa di tengah Pandemik COVID-19, di Kota Sorong, Papua Barat).” Civic-Culture: Jurnal Ilmu Pendidikan PKn dan Sosial Budaya Vol. 4, no. N. 1 (2020): 32-44.

Mahmudah, Safira Rona. "Pengaruh Pembelajaran Daring terhadap Psikologis Siswa Terdampak Social Distancing Akibat Covid 19." Jurnal Al - Mau'izhoh Vol.2, no. No. 2 (2020): 1-14.

Makinuddin, Mohammad, Saeful Anam, dan Shoffiyah. "Character Building dan Pendidikan Islam di Era New Normal.” MIYAH: Jurnal Studi Islam Vol. 16, no. No. 1 (2020): 186-99.

Megawanti, Priarti, Erna Megawati, dan Siti Nurkhafifah. "Persepsi Peserta Didik Terhadap PJJ Pada Masa Pandemi Covid 19.” Faktor Jurnal Ilmiah Kependidikan Vol. 7, no. No. 2 (2020): 75-82.

Meutia, Amalia. "Dampak Pandemi Covid 19 Pada Psikis Dan Ingatan Anak." ESJ (Elementary School Journal) Vol. 10, no. No. 1 (2020): 60-66.

Palupi, Tri Nathalia. "Tingkat Stres Pada Siswa-Siswi Sekolah Dasar Dalam Menjalankan Proses Belajar Di Rumah Selama Pandemi Covid-19.” JP3SDM Vol. 9, no. No. 2 (2020): 18-29. 
Putro, Khamim Zarkasih, Muhammad Adly Amri, Nuraisah Wulandari, dan Dedek Kurniawan. "Pola Interaksi Anak Dan Orangtua Selama Kebijakan Pembelajaran di Rumah." Fitrah: Journal of Islamic Education Vol. 1, no. No. 1 (2020): 125-40.

Raharjo, Anang Susilo, dan dkk,. Kutunggu Hadirmu di Depan Layar. Sumatera Utara: format publishing, 2020. https://formatpublishing.id.

Rahmasari, Aden Fani, Fajar Setiawan, dan Meirza Nanda Faradita. "Pengaruh Pembelajaran Online Terhadap Kemandirian Belajar Siswa Kelas II SD Muhammadiyah 17 Surabaya di Tengah Pandemi Covid-19." Inventa: Jurnal Pendidikan Sekolah Dasar Vol. 4, no. No. 5 (2020): 158-68.

Rais, Haidar. "Update covid-19 di Indonesia." Go.id. prfmnews.id (blog), 2020.

Rinawati, Desy, dan Eka Kurnia Darisman. "Survei tingkat kejenuhan siswa SMK belajar di rumah pada mata pelajaran produk kreatif dan kewirausahaan selama masa pandemi covid-19." Journal of Science and Education (JSE) Vol. 1, no. No. 1 (2020): 32-40.

Risalah, A, W Ibad, L Maghfiroh, M I Azza, S A Cahyani, dan Z A Ulfayati. "Dampak pandemi covid-19 terhadap kegiatan belajar mengajar di MI/SD (studi KBM berbasis daring bagi guru dan siswa)." JIEES : Journal of Islamic Education at Elementary School Vol. 1, no. No. 1 (2020): 10-16.

Rohayani, Farida. "Menjawab Problematika Yang Dihadapi Anak Usia Dini di Masa Pandemi COVID-19." QAWWAM: JOURNAL FOR GENDER MAINSTREAMING Vol. 14, no. No. 1 (2020): 29-50. https://doi.org/10.20414/Qawwam.v14i1.2310.

Sadikin, Ali, dan Afreni Hamidah. "Article Pembelajaran Daring di Tengah Wabah Covid-19." BIODIK: Jurnal Ilmiah Pendidikan Biologi Vol. 6, no. No. 2 (2020): 214-24.

Sari, Neneng Yulda, dan Wisroni. "The Urgency Of Parental Guidance For Youth Education In The Belajar Dari Rumah (BDR) Era." Jurnal Pendidikan Luar Sekolah (PLS) Vol. 8, no. No. 3 (2020): 309-21. https://doi.org/10.24036/spektrumpls.v8i3.109565.

Setyorini, In. "Pandemi covid-19 dan online learning: apakah berpengaruh terhadap proses pembelajaran pada kurukulum 13?" Journal of Industrial Engineering \& Management Research (JIEMAR) Vol. 1, no. No. 1 (2020): 95-102. https://doi.org/10.7777/jiemar.v1i1.

Setyosari, Punaji. Metode penelitian pendidikan dan pengembangan. Jakarta: Prenada Media, 2016.

Subarto. "Momentum Keluarga Mengembangkan Kemampuan Belajar Peserta Didik Di Tengah Wabah Pandemi Covid-19." 'Adalah: Buletin Hukum dan Keadilan Vol. 4, no. No. 1 (2020): 13-18. https://doi.org/10.15408/adalah.v4i1.15383.

Sugihantono, Anung, dan dkk,. Pedoman Pencegahan dan Pengendalian Coronavirus Disesase (Covid-19). Jakarta: Kementerian Kesehatan RI, 2020. https://infeksiemerging.kemkes.go.id.

Sugiyono. metode penelitian kombinasi (mixed methods). Bandung: Penerbit Alfabeta, 2016. 
Tabi'in, A. "Problematika Stay At Home Pada Anak Usia Dini Di Tengah Pandemi Covid 19." Jurnal Golden Age, Universitas Hamzanwadi Vol. 04, no. No. 1 (2020): 190-200.

Tim Penyusun Kamus Pusat Bahasa. Kamus Bahasa Indonesia. Jakarta: Pusat Bahasa, 2008.

Wardani, Anita, dan Yulia Ayriza. "Analisis Kendala Orang Tua dalam Mendampingi Anak Belajar di Rumah Pada Masa Pandemi Covid-19." Jurnal Obsesi : Jurnal Pendidikan Anak Usia Dini Vol. 5, no. No. 1 (2020): 772-82. https://doi.org/10.31004/obsesi.v5i1.705.

Wicaksono, Adhi. "KPAI Sebut siswa bunuh diri diduga banyak tugas selama PJJ." Transmedia. CNNIndonesia.com (blog), 2020. https://m.cnnindonesia.com/nasional/20201031194605-20-564467/kpai-sebutsiswa-bunuh-diri-diduga-banyak-tugas-selama-pjj.

Yunitasari, Ria, dan Umi Hanifah. "Pengaruh Pembelajaran Daring terhadap Minat Belajar Siswa pada Masa COVID-19." Edukatif: Jurnal Ilmu Pendidikan Vol. 2, no. No. 3 (2020): 232-43.

Yunus, Muhammad. "Siswi Bunuh Diri Di Gowa, Kpai Sayangkan Pernyataan Fitri Ari Utami." Suara.com. Suarasulsel.id (blog), 2020. https://sulsel.suara.com/read/2020/10/22/165903/siswi-bunuh-diri-di-gowa-kpaisayangkan-pernyataan-fitri-ari-utami. 